\title{
PENGEMBANGAN MOBILE LEARNING BERORIENTASI MODEL PEMBELAJARAN FLIPPED CLASSROOM PADA MATA KULIAH MULTIMEDIA
}

\author{
Adrianus I Wayan Ilia Yuda Sukmana \\ Jurusan Teknologi Pendidikan, Universitas Pendidikan Ganesha \\ E-mail: yudasukmanaTP13@gmail.com \\ I Kadek Suartama \\ Jurusan Teknologi Pendidikan, Universitas Pendidikan Ganesha \\ E-mail:deksua@gmail.com
}

\begin{abstract}
Abstrak
Penelitian ini merupakan penelitian pengembangan yang tujuan: 1) mengetahui rancang bangun mobile learning berorientasi model pembelajaran flipped classroom pada mata kuliah multimedia Jurusan TP FIP Undiksha, 2) mengetahui kelayakan mobile learning berorientasi model pembelajaran flipped classroom pada mata kuliah multimedia Jurusan TP FIP Undiksha, dan 3) mengetahui keefektifan mobile learning berorientasi model pembelajaran flipped classroom pada mata kuliah multimedia Jurusan TP FIP Undiksha. Subjek coba penelitian ini adalah satu orang ahli isi, satu orang ahli media pada tahapan uji validasi serta 12 mahasiswa Jurusan TP FIP Undiksha semester VIII 2016/2017 pada tahap evaluasi formatif. Pada tahap evaluasi sumatif (uji efektivitas) dipilih mahasiswa Jurusan TP FIP Undiksha Semester VII Tahun Akademik 2017-2018. Instrumen pengumpulan yang digunakan pada penelitian ini adalah angket dan tes hasil belajar. Hasil penelitian pengembangan ini menunjukkan bahwa hasil uji pada masing-masing tahap berada pada kategori baik dan layak digunakan dalam pembelajaran
\end{abstract}

Kata-kata kunci: pengembangan, mobile learning, flipped classroom, multimedia

\begin{abstract}
This study was research and development ( R\&D) that aims to: 1) know the design of flippled classroom modeled mobile-learning for multimedia course at Educational Technology Departement in Undiksha , 2) know the approprieteness of flipled-classroom modeled mobile-learning for multimedia course at Educational Technology Departement in Undiksha, and 3) know the effectiveness of of flipled-classroom modeled mobile-learning for multimedia course at Educational Technology Departement in Undiksha, The subjects of this study are The subject of this research are: one content expert, one media expert on the validation-test stage and 12 students of Educational Technology Departement semester VIII period 2017/2018 on the formative-test stage. In sumative-evaluation stage (effectiveness test, the student that was selected cames from semester VII students of Educational Technology Departement in Faculty of Education in Undiksha period 2017-2018. instrument of data collection in this study are questionnaires and learning-result tests. The results of this development and research study (R \& D) indicate that the test-results at each stage are in good category and suitable for use in learning.
\end{abstract}

Keywords: development, mobile learning, flipped classroom, multimedia

\section{PENDAHULUAN}

Di dalam pelaksanaan proses pembelajaran seperti saat ini, seyoganya pembelajaran berlangsung secara efektif, efisien, inovatif serta diarahkan pada proses pembajaran yang berpusat pada siswa. Namun, realita berkata lain. Penyampaian materi dalam pembelajaran yang berlangsung kerap kali berpusat pada pengampu materi pembelajaran serta kecenderungan kurang jelas dan berpotensi mengurangi pemahaman mahasiswa. Mahasiswa terkadang susah dalam menerima materi yang diberikan oleh dosen terlebih lagi saat di dalam kelas mahasiswa lebih sering tidak memperhatikan dosen, baik karena malas maupun karena memang kondisi kelas yang tidak mendukung. Hal ini kemudian menyebabkan capaian pembelajaran yang diinginkan tidak tercapai. Fenomena ini didukung oleh penelitian yang dilakukan oleh Mustaji (2012) tentang penyebab pembelajaran di perguruan tinggi belum optimal. Temuan dari penelitian yang dilakukan oleh mustaji yaitu 1) penyelenggaraan proses pembelajaran saat ini masih kurang esuai dengan tuntutan perkembangan dibidang teknologi pembelajaran, 2) pembelajar seringkali keliru dalam memandang proses pembelajaran, dan 3) pembelajar menggunakan konsep-konsep pembelajaran yang tidak relevan dengan perkembangan teknologi pembelajaran. 
Merujuk hal tersebut diatas, inovasi dalam pembelajaran perlu dilakukan agar bisa mengoptimalkan proses dan hasil belajar. Inovasi pembelajaran saat ini semakin dirasa perlu dilakukan terutama dengan memanfaatkan perkembangan Information and Communication Technology (ICT). Inovasi pembelajaran yang dimaksud adalah inovasi yang dapat meningkatkan kemampuan mahasiswa dalam menyelesaikan masalah, mengembangkan kreatifitas, kemampuan kolaboratif, kemampuan komunikasi, dan meningkatkan hasil belajar.

Tidak dipungkiri bahwa cepatnya perkembangan ilmu pengetahuan dan teknologi telah begitu berperngaruh dibanyak bidang. Salah satunya adalah di bidang pendidikan. Bisa dilihat saat ini internet sangat membantu dalam proses belajar bahkan pencarian materi pelajaran pun menjadi mudah. Teknologi kini bahkan berkembang menjadi sangat fleksibel dalam hal mobilitas kerja. Contohnya adalah keberadaan hanphone/smartphone ditengah masyarakat. Dengan menggunakan smartphone orang dapat mengakses internet dimanapun dan kapanpun untuk memenuhi kebutuhannya akan informasi.

Dari pengamatan yang dilakukan, sebagian besar mahasiswa lebih suka mengakses informasi melalui handphone mereka daripada menggunakan laptop maupun komputer. Dengan handphone mereka dapat mengakses informasi kapanpun dan dimanapun. Dari pengataman ini, teknologi internet dan handphone ini dapat dimanfaatkan sebagai media pembelajaran yang menawarkan kemudahan bagi penggunanya yaitu sebagai media pembelajaran yang dikemas dalam bentuk "mobile learning”.

Adapun perangkat mobile pada dasarnya memiliki tingkat fleksibilitas dan portabilitas yang tinggi sehingga memungkinkan mahasiswa mengakses materi, arahan dan informasi yang berkaitan dengan pembelajaran kapanpun dan dimanapun. Menurut Yuniati (2011), mobile learning mampu menjadikan handphone yang awalnya hanya digunakan untuk sms, telepon, chatting, dan internet menjadi alat belajar lengkap yang berisi materi pelajaran. Selain itu, peserta didik dapat menggunakan waktu belajarnya dengan lebih leluasa dan memiliki kesempatan lebih besar untuk meningkatkan hasil belajarnya. Mobile learning juga dapat dijadikan sebagai salah satu alternatif untuk memecahkan permasalahan dalam bidang pendidikan terutama pada masalah pemerataan akses infomasi pendidikan, kualitas konten pembelajaran yang berupa materi dengan bentuk teks ataupun gambar disertai dengan contoh-contoh soal serta peningkatan kualitas pengajar atau guru agar lebih baik dalam membuat atau menyampaikan materi pembelajaran dan mengelola kegiatan belajar mengajar. Mobile learning memberikan harapan baru sebagai alternatif solusi atas sebagian besar permasalahan pendidikan, dengan fungsi yang dapat disesuikan dengan kebutuhan, baik sebagai suplemen (tambahan), komplemen (pelengkap), ataupun substitusi (pengganti) atas kegiatan pembelajaran di dalam kelas yang selama ini digunakan. Mobile learning juga dapat dikombinasikan dengan berbagai metode dan model pembelajaran yang digunakan oleh guru dalam kegiatan pembelajaran.

Berdasarkan temuan dilapangan pada mata kuliah multimedia di Fakultas Ilmu Pendidikan, diperoleh masukan dari mahasiswa yang disampaikan melalui Sistem Infomasi Akademik (SIAK) Universitas Pendidikan Ganesha (Undiksha), bahwa pembelajaran selama ini masih didominasi oleh dosen, kurang mengaktifkan mahasiswa, dan ke depan perlu dirancang pembelajaran yang dapat mengaktifkan mahasiswa. Selain itu mahasiswa merasakan kekurangan waktu belajar di kelas mengingat materi mata kuliah Multimedia sangat banyak karena terdiri dari materi yang sifatnya konsep teoritik dan materi yang sifatnya praktik emperik.

Dengan mengemas kegiatan pembelajaran semenarik mungkin maka minat mahasiswa dalam mengikuti pembelajaran pun akan semakin tinggi. Salah satu cara untuk membentuk kegiatan pembelajaran yang menyenangkan adalah dengan menerapkan strategi belajar flipped classroom. Johnson (2013) mendefinisikan flipped classroom sebagai strategi yang dapat diberikan oleh dosen dengan cara meminimalkan jumlah instruksi langsung dalam praktek mengajar mereka sambil memaksimalkan interaksi satu sama lain. Dalam persiapan untuk belajar dikelas, mahasiswa diwajibkan untuk melihat video pembelajaran, website atau tutorial tertentu yang dapat diaskses melalui handphone mereka yang terkoneksi internet. Flipped Classroom dapat juga didefinisikan sebagai model pembelajaran yang "membalik" metode tradisional, di mana biasanya materi diberikan di kelas dan mahasiswa mengerjakan tugas di rumah. Konsep Flipped Classroom mencakup active learning, keterlibatan mahasiswa, dan podcasting. Dalam flipped classroom, materi terlebih dahulu diberikan melalui teks, audio, video, animasi, atau multimedia pembelajaran yang harus pelajari mahasiswa di rumah masing-masing. Sebaliknya, sesi belajar di kelas digunakan untuk diskusi kelompok dan mengerjakan tugas. Di sini, dosen berperan sebagai pembina atau pemberi saran.

Berdasarkan paparan tersebut, maka dilakukanlah penelitian pengembangan perangkat Mobile Learning Berorientasi Model Pembelajaran Flipped Classroom Pada Mata Kuliah Multimedia Jurusan Teknologi Pendidikan Fakultas Ilmu Pendidikan Universitas Pendidikan Ganesha. 


\section{METODE PENELITIAN}

Penelitian ini adalah penelitian pengembangan dengan model pengembangan yang diadaptasi langkahlangkah penelitian dan pengembangan yang dikemukakan oleh Borg \& Gall (1983) sedangkan dari aspek proses pembelajaran, model desain pembelajaran yang digunakan dalam mengembangkan konten pembelajaran dalam perangkat mobile learning ini adalah model Dick \& Carey (2005). Desain evaluasi produk digunakan model evaluasi program media oleh Arief S. Sadiman (2009) yakni pada tahapan evaluasi formatif dalam bentuk validasi para ahli dan evaluasi lapangan (field evaluation) serta evaluasi sumatif dalam bentuk pengukuran hasil belajar.

Pihak-pihak yang dijadikan subjek coba dalam pengembangan mobile learning ini yaitu satu orang ahli materi, ahli desain pembelajaran dan satu orang ahli media pada tahapan validasi media. Pada uji coba produk tahap evaluasi formatif (uji kelayakan), yang menjadi subjek coba adalah mahasiswa Jurusan Teknologi Pendidian Universitas Pendidikan Ganesha Semester VIII tahun akademik 2016-2017 sebanyak 12 orang mahasiswa sedangkan pada tahap evaluasi sumatif (uji efektivitas) subjek coba adalah mahasiswa Jurusan Teknologi Pendidian Universitas Pendidikan Ganesha Semester Semester VII tahun akademik 20172018.

Instrumen yang digunakan untuk mengumpulkan data pada penelitian ini adalah angket, dan tes hasil belajar. Angket disusun dengan maksud untuk mengetahui kelayakan mobile learning. Tes hasil belajar digunakan untuk mendapatkan skor hasil belajar pretest dan posttest pada kelas yang menggunakan mobile learning.

Data yang diambil dalam penelitian ini berupa data kualitatif dan data kuantitatif. Data kualitatif dalam penelitian ini adalah data yang diperoleh dari tanggapan mengenai aspek materi, pembelajaran, tampilan dan pemrograman dari berbagai sumber yaitu ahli materi, ahli media dan mahasiswa. Data kualitatif ini diangkakan (scoring) sehingga data kualitatif dalam penilaian ini berubah menjadi data kuantitatif. Data kuantitatif lainnya diperoleh dari skor mahasiswa pada pretest dan posttest serta skor dari penilaian karakter mahasiswa.

Teknik yang digunakan untuk mengetahui efektivitas produk yang dibuat dapat dilihat dalam bentuk perbedaan skor pre test dan post test.

Data pretest dan posttest yang diperoleh kemudian diperhitungkan besaran posttest-pretest (gain skor). Gain skor tersebut memperlihatkan derajat efektivitas penggunaan multimedia pembelajaran. Untuk menghitung gain skor dapat digunakan rumus sebagai berikut.

Gain Skor $=\frac{s \text { post-s pre }}{s \text { maks-spre }}$

Keterangan:

S post : Skor posttest

$S$ pre : Skor pretest

S maks: Skor maksimum ideal

Kriteria perolehan gain skor menggunakan acuan tabel yang diadaptasi dari Dantes (2014) sebagai berikut.

Tabel 1

Kategori perolehan gain skor

\begin{tabular}{|c|c|}
\hline Batasan & Kategori \\
\hline $\mathrm{g}>0,7$ & Tinggi \\
\hline $0,3<\mathrm{g} \leq 0,7$ & Sedang \\
\hline $\mathrm{g} \leq 0,3$ & Rendah \\
\hline
\end{tabular}

\section{HASIL DAN PEMBAHASAN}

\section{HASIL PENELITIAN}

Pengujian yang dilakukan terhadap produk mobile learning ini terdiri dari dua tahap. 1) tahap uji kelayakan dan; 2) uji efektivitas produk. Uji kelayakan yang dilakukan terhadap media yang telah dikembangkan ini meliputi beberapa tahap, yaitu validasi oleh ahli materi, validasi oleh ahli media, dan uji coba lapangan.

Hasil penilaian ahli materi terhadap kualitas produk ditinjau dari aspek pembelajaran diketahui bahwa rerata skor sebesar 4,36 (kategori sangat baik) dan dari aspek materi/isi sebesar 4, 33 (kategori sangat baik). 
Hasil penilaian ahli media terhadap kualitas produk ditinjau dari aspek tampilan diketahui bahwa rerata skor sebesar 4,14 (kategori baik) dan dari aspek pemrograman sebesar 4,11 (kategori baik).

Hasil penilaian secara keseluruhan aspek pada uji coba lapangan menunjukkan bahwa untuk aspek pembelajaran diperoleh skor 4,55 (kategori sangat baik), aspek isi/materi sebesar 4,45 (kategori sangat baik), aspek tampilan sebesar 4,43 (kategori sangat baik), dan aspek pemrograman sebesar 4,44 (kategori sangat baik).

Memperhatikan aspek-aspek tersebut dapat disimpulkan bahwa Pengembangan Mobile Learning Berorientasi Model Pembelajaran Flipped Classroom Pada Mata Kuliah Multimedia yang dikembangkan termasuk kategori sangat baik sehingga dapat disimpulkan media layak untuk digunakan.

Uji efektivitas dilakukan untuk mengetahui seberapa besar produk yang dikembangkan dapat meningkatkan kualitas pembelajaran dalam bentuk peningkatan pencapaian hasil belajar mahasiswa setelah mengunakan produk mobile-learning yang dikembangkan. Dalam uji efektivitas ini digunakan mahasiswa jurusan Teknologi Pendidikan semester VII pada mata kuliah Multimedia Pembelajaran. Teknik yang digunakan untuk mengetahui efektivitas produk yang dibuat perbedaan skor pretest dan posttest. Data pretest dan posttest yang diperoleh kemudian diperhitungkan besaran posttest-pretest (gain skor). Gain skor tersebut memperlihatkan derajat efektivitas penggunaan mobile learning. Berikut adalah hasil perhitungan Gain skor.

Gain Skor $=\frac{s \text { post }-s \text { pre }}{s \text { maks }-s \text { pre }}$

Berdasarkan pengujian yang dilakukan, diperoleh gain skor sebesar 0,79

Dari data tersebut, setelah dikonversi dengan tabel kategori perolehan gain skor, dapat disimpulkan bahwa gain skor antara nilai pretest dan posttest berada kategori tinggi dengan demikian dapat dikatakan bahwa efektivitas mobile learning berada pada kategori tinggi.

\section{PEMBAHASAN}

Berdasarkan tanggapan dan hasil belajar mahasiswa dengan menggunakan perangkat mobile-learning yang dikembangkan, produk ini dari segi kelayakan dapat dikatakan sangat baik dan memiliki tingkat interaktifitas yang baik serta mampu membuat mahasiswa aktif dalam proses pembelajaran. Ketertarikan mahasiswa terhadap media pembelajaran merupakan salah satu indikator dari adanya motivasi belajar pada mahasiswa dan merupakan gejala yang sangat baik untuk menuju peningkatan proses dan hasil belajar. Unsur-unsur tampilan yang dapat dipandang menarik dari produk mobile-learning ini diantaranya adalah home page, kemudahan navigasi, serta perpaduan warna teks dan background yang sangat harmonis.

Selain tampilan yang menarik, dalam setiap pokok bahasan, media ini dilengkapi dengan contoh gambar, animasi, maupun video sehingga mahasiswa atau pengguna dapat lebih memahaminya. Produk mobile-learning ini memiliki keunggulan lain yaitu adanya feedback langsung yang diberikan dosen terhadap tugas-tugas yang dikerjakan ahasiswa. Umpan balik ini berupa penguatan positif maupun penguatan negatif dari dosen.

Tentang kemudahan penggunaan produk e-learning ini diakui pula oleh mahasiswa. Dengan hanya mengetikkan url: edutechsmart.com pada browser mahasiswa sudah dapat menggunakan portal mobilelearning ini. Melalui produk mobile-learning materi pembelajaran dapat diakses dengan lebih cepat, kapan saja, dan dari mana saja, disamping itu materi yang dapat diperkaya dengan berbagai sumber belajar termasuk multimedia dengan cepat dapat diperbaharui oleh dosen. Mahaiwa juga melakukan monitoring, komunikasi, dan kerjasama. Di sisi lain mahasiswa tentu saja dapat mengunduh materi pembelaaran, mengerjakan tugas-tugas dan kuis, serta berpartisipasi dalam chating dan forum diskusi.

Desain pembelajaran dalam mobile-learning ini menggunakan model flipped classroom. Pembelajaran menekankan kepada aktivitas mahasiswa secara maksimal untuk mencari dan menemukan (menempatkan mahasiswa sebagai subjek belajar). Dalam proses pembelajaran, mahasiswa tidak hanya berperan sebagai penerima pelajaran melalui penjelasan dosen secara verbal, tetapi mereka berperan untuk menemukan sendiri inti dari materi pelajaran itu sendiri. Seluruh aktivitas yang dilakukan siswa diarahkan untuk mencari dan menemukan jawaban sendiri dari sesuatu yang dipertanyakan, sehingga dapat menumbuhkan sikap percaya diri (self belief), mengembangkan kemampuan intelektual sebagai bagian dari proses mental.

Portal dan course e-learning (mobile-learning) untuk pada mata kuliah multimedia pembelajaran ini dapat meningkatkan efektivitas pembelajaran mata kuliah multimedia pembelajaran. Hal ini dibuktikan dengan adanya perbedaan yang signifikan mengenai hasil belajar mata kuliah multimedia pembelajaran sebelum dan sesudah menggunakan mobile-learning. Gain skor menunjukkan angkat 0,79, maka dapat disimpulkan ada perbedaan hasil belajar yang signifikan sebelum dan sesudah menggunakan mobile-learning Edutech Smart pada mahasiswa semester VII tahun akademik 2017-2018 mata kuliah multimedia pembelajaran. Hasil belajar mahasiswa sesudah menggunakan produk akhir yang telah dikembangkan berupa 
mobile-learning Edutech Smart lebih baik dibanding hasil belajar mahasiswa sebelum menggunakan produk akhir yang telah dikembangkan berupa mobile-learning Edutech Smart. Dari hasil tersebut dapat dikatakan bahwa media pembelajaran yang dikembangkan efektif dan dapat meningkatkan kualitas pembelajaran pada mata kuliah multimedia pembelajaran.

\section{KESIMPULAN}

Berdasarkan analisis data diatas, dapat ditarik kesimpulan sebagai berikut.

Rancang bangun pengembangan portal dan course mobile-learning mata kuliah multimedia pembelajaran ini melalui lima tahapan yaitu analisis kebutuhan, tahap mendesain pembelajaran, memproduksi produk, melakukan evaluasi formatif dan sumatif. Semua tahapan telah dilakukan hingga menghasilkan produk course mobile-learning yang layak dan efektif pada pembelajaran mata kuliah multimedia.

Ditinjau dari aspek kualitas, Portal dan course e-learning pada mata kuliah multimedia pembelajaran ini tergolong layak digunakan sebagai media pembelajaran. Dari hasil penilaian ahli materi ditinjau dari aspek pembelajaran diketahui bahwa rerata skor sebesar 4,36 (kategori sangat baik) dan dari aspek materi/isi sebesar 4, 33 (kategori sangat baik). Hasil penilaian ahli media terhadap kualitas produk ditinjau dari aspek tampilan berada pada kategori baik (dengan skor 4,14) dan dari aspek pemrograman sebesar 4,11 (kategori baik). Hasil penilaian secara keseluruhan aspek pada uji coba lapangan menunjukkan bahwa untuk aspek pembelajaran diperoleh skor 4,55 (kategori sangat baik), aspek isi/materi sebesar 4,45 (kategori sangat baik), aspek tampilan sebesar 4,43 (kategori sangat baik), dan aspek pemrograman sebesar 4,44 (kategori sangat baik).

Produk mobile-learning pada mata kuliah multimedia pembelajaran ini dapat meningkatkan efektivitas pembelajaran mata kuliah multimedia pembelajaran. Hal ini dibuktikan dengan adanya perbedaan yang signifikan mengenai hasil belajar mata kuliah multimedia pembelajaran mahasiswa jurusan TP semester VII tahun akademik 2017-2018 sebelum dan sesudah menggunakan produk mobile-learning yang dilihat dari nilai Gain skor yaitu sebesar 0,79 .

\section{DAFTAR RUJUKAN}

Arief S. Sadiman, et al. (2009). Media pendidikan: pengertian, pengembangan dan pemanfaatannya. Jakarta: Rajawali Pers

Azhar Arsyad. (2009). Media pembelajaran. Jakarta: Rajawali Pers.

Borg, W.R., \& Gall, M.D. (1983). Educational research. An introduction (4 ${ }^{\text {th }}$ ed.) New York: Longman.

Chee, T.S. \& Wong. A.F.L. (2003). Teaching and learning with technology. Singapore: Prentice Hall.

Dantes. N. (2014). Desain dan Analisis Eksperimen. Singaraja: PPs Undiksha

Dean N. Shimamoto. 2012. Implementing a Flipped Classroom: An Instructional Module. Hawai Amerika Serikat: Department of Educational Technology University of Hawaii Manoa.

Dick, W. \& Carey, L. (2005). The systematic design of instruction (6 $6^{\text {th }}$ ed.). Illinois: Scott, Foresman and Company.

Georgiev, Tsvetozar, Evgeniya Georgieva, Angel Smrikarov. 2005. A General Classification of Mobile Learning Systems, International Conference on Computer Systems and TechnologiesCompSysTech'.http://ecet.ecs.ru.acad.bg/cst05/Docs/cp/sIV/IV.14.pdf, Diakses 23 Desember 2016.

Guilford, JP. 1973. Fundamental Statistic in Psychology and Education. Tokyo : Mc Graw-Hill Kogakhusa LTD.

Haryono. 2011. Pengenalan E-learning. Jurnal Dharma Pendidikan. Didownload pada tangal 15 Agustus 2011 dari http://dharmapendidikan.blogspot.com/2011/03/pengenalan-e-learning.html

Herman Dwi Surjono. 2010. Pengembangan Course E-learning Berbasis Moodle. Yogyakarta: UNY Press

Holzinger, Andreas, Alexander Nischelwitzer, dan Matthias Meisenberger. 2005. Mobile Phones as a Challenge for m-Learning:Experiences with the Mobile Learning Engine (MLE) using Mobile Interactive Learning Objects (MILOs). http://dmt.fhjoanneum.at/kd3/objects/application_pdf/percom 2004\%20hawaii_PerIL_ah_nis.

Johnson, Graham Brent. 2013. Student Perceptions of The Flipped Classroom. Columbia: The University Of British Columbia.

Jonathan, Bregmann dan Aaron Sams. 2012. Flipp Your Classroom. United States of America: International Society for Technology in Education.

Lee, W.W., \& Owens, D.L. 2004. Multimedia Base Instrucion Design: Computer Based Training, Web Based Training, Distance Broadcast Training, Performance Based Solution (2 ${ }^{\text {nd }}$ ed.). San Fransisco: Pfeiffer A Wiley Imprint.

Luis Tirtasanjaya, Teo Chin Wen, dkk. 2012. Assessing the effectiveness of flipped classroom pedagogy in promoting students' learning experience. NYGH Research Journal. 
Merrill, Paul F., et al. (1996). Computers in eucation (3 ${ }^{\text {rd }}$ ed.) Englewood Cliffs, NJ: Eucational Technology Publication.

Mustaji. 2012. Desain pembelajaran dengan menggunakan model pembelajaran kolaborasi untuk meningkatkan kemampuan berkolaborasi. [Online]. Tersedia di: http://pasca.tp.ac.id/site/desainpembelajaran-denganmenggunakan-model-pembelajaran-kolaborasi-untuk-meningkatkankemampuanberkolaborasi. [Diakses 4 Februari 2014]

Newby, T.J. et al. (2000). Instructional technology for teaching and learning. New Jersey: Prentice-Hall Inc

Nicola Sales. 2013. Flipped the Classroom: Revolutionising Legal Research Training.Cambridge Journals. Vol. 13. Pp 231-235.

Phillips, R. (1997). The developer's handbook to interactive multimedia: A practical guide for educational applications. London: Kogan Page.

Pierce, Richard EdD and Jeremy Fox, PharmD. 2012. Instructional Design And Assessmentvodcasts And Active-Learning Exercises In A “Flipped Classroom” Model Of A Renal Pharmacotherapy Module. American Journal of Pharmaceutical Education 2012; 76 (10) Article 196.

Purwanto. (2009). Evaluasi Hasil Belajar. Yogyakarta: Pustaka Pelajar

Romi Satria Wahono. 2008. Memilih Sistem E-Learing Berbasis Open Source. Didownload pada tanggal 22 Maret 2013 dari http://romisatriawahono.net/2008/01/24/memilih-sistem-e-learning-berbasis-opensource/

Santyasa, I W. 2006. Metodologi Penelitian Peningkatan Kualitas Pembelajaran (PPKP). Makalah Disajikan dalam Pelatihan Para Dosen Undiksha tentang Penelitian Tindakan Kelas dan Penelitian untuk Peningkatan Kualitas Pembelajaran di Perguruan Tinggi. Singaraja: Nopember

Smaldino, S.E., Lowther, D.L., \& Russell, J.D. (2007). Instructional technology and media for learning $\left(9^{\text {th }}\right.$ ed.). New Jersey: Pearson Education, Inc.

Songhaao, H. et. Al. 2011. Evolution From Collaborative Learning to Symbiotic E-learning: Creation of New E-learning Environment for Knowledge Society. US-China Education Review, 8(1), 46-53, Didownload pada tanggal 14 Pebruari 2012 di http://www.eric.ed.gov/PDFS/ED519417.pdf

Sugiyono. (2009). Metode penelitian kuantitatif kualitatif dan R\&D. Bandung: Alfabeta

Sukardjo, (2010). Evaluasi Pembelajaran. Buku Pegangan Kuliah: PPs Universitas Negeri Yogyakarta

Yuniati, Lukita. 2011. Pengembangan Media Pembelajaran Mobile Learning Efek Doppler sebagai Alat Bantu dalam Pembelajaran Fisika JP2F. Vol 2 Nomer 2 September 92-101.

Yusufhadi Miarso. (2004). Menyemai benih teknologi pendidikan. Jakarta: Kencana 